\title{
Analisis Rencana Pelaksanaan Pembelajaran Kurikulum 2013 Berdasarkan Indikator Kemampuan Imajinasi Matematis Siswa
}

\author{
Novi Andri Nurcahyono ${ }^{1 *}$, \& Eka Novarina ${ }^{2}$ \\ ${ }^{1}$ Universitas Muhammadiyah Sukabumi, Sukabumi, Indonesia \\ ${ }^{2}$ BBPPKS Bandung, Bandung, Indonesia
}

\begin{tabular}{l}
\hline INFO ARTICLES \\
\hline Article History: \\
Received: $22-12-2020$ \\
Revised: $24-12-2020$ \\
Approved: $24-12-2020$ \\
Publish Online: $25-12-2020$ \\
\hline
\end{tabular}

Key Words:

Mathematical Imagination Abilities; The 2013 Curriculum; Lesson Plan;

\section{cc) (7) (2)} under a Creative Commons AttributionShareAlike 4.0 International License.

\begin{abstract}
The ability of mathematical imagination is needed to understand everything about facts, concepts, principles and procedures in learning mathematics. Thus, the ability of students' mathematical imagination in mathematics learning needs to be developed. The students examined in this research are limited to grade 8 junior high school students. Developing junior high school students' mathematical imagination skills begins with making appropriate lesson plans. Making lesson plans must be adjusted to the curriculum that is being used. Currently, Indonesia uses The 2013 Curriculum. Viewed from the goals of The 2013 Curriculum, which are creative and innovative, The 2013 Curriculum provides space and priority for junior high school students in developing their mathematical imagination skills. Parts of the lesson plan that can be shown by mathematical imagination are learning objectives, basic competencies and competency achievement indicators, learning methods, learning media, learning sources and learning steps.
\end{abstract}

\begin{abstract}
Abstrak: Kemampuan imajinasi matematis dibutuhkan untuk memahami segala sesuatu mengenai fakta, konsep, prinsip, dan prosedur di dalam pembelajaran matematika. Sehingga, kemampuan imajinasi metematis siswa dalam pembelajaran matematika perlu dikembangkan. Adapun siswa yang dikaji dalam artikel ini dibatasi yakni siswa SMP kelas 8. Mengembangkan kemampuan imajinasi matematis siswa SMP dimulai dengan membuat perencanaan pembelajaran yang tepat. Pembuatan RPP harus disesuaikan dengan kurikulum yang sedang digunakan. Saat ini, Indonesia menggunakan Kurikulum 2013. Dilihat dari tujuan Kurikulum 2013 yaitu kreatif dan inovatif, Kurikulum 2013 memberikan ruang dan prioritas bagi siswa SMP dalam mengembangkan kemampuan imajinasi matematis. Bagian-bagian RPP yang dapat dimunculkan imajinasi matematika adalah tujuan pembelajaran, KD dan indikator pencapaian kompetensi, metode pembelajaran, media pembelajaran, sumber belajar, dan langkah-langkah pembelajaran.
\end{abstract}

Correspondence Address: Jln. R. Syamsudin, S.H. No. 50, Kota Sukabumi, Kode Pos 43113, Negara Indonesia; $e$ mail: nanurcahyono@gmail.com

How to Cite (APA ${ }^{\text {th }}$ Style): Nurcahyono, N.A., \& Novarina, E. (2020). Analisis Rencana Pelaksanaan Pembelajaran Kurikulum 2013 Berdasarkan Indikator Kemampuan Imajinasi Matematis Siswa. JKPM (Jurnal Kajian Pendidikan Matematika), 6(1): 121-130.

Copyright: 2020 Novi Andri Nurcahyono, Eka Novarina

Competing Interests Disclosures: The authors declare that they have no significant competing financial, professional or personal interests that might have influenced the performance or presentation of the work described in this manuscript. 


\section{PENDAHULUAN}

Seorang ilmuan besar dalam sejarah yaitu Albert Einstein (Calaprice, 2011: 12) mengatakan "imajinasi lebih penting daripada ilmu pengetahuan". Di saat seseorang membayangkan hal-hal yang tidak bisa dilihat, didengar, dicicipi, disentuh, atau dicium, maka sebenarnya imajinasi sedang digunakan. Vygotsky (2004) mengatakan bahwa imajinasi adalah kemampuan mental lebih tinggi yang melibatkan proses pemikiran yang diarahkan secara sadar dan dasar dari semua kegiatan kreatif, baik dalam seni maupun sains. Imajinasi atau sering disebut juga kemampuan membayangkan memiliki pengertian bahwa kemampuan untuk membentuk gambar baru dan sensasi yang tidak dirasakan melalui penglihatan, pendengaran atau indera lainnya (http://en.wikipedia.org). Dalam pendapat lain, Samli (2011) menyatakan bahwa imajinasi adalah kemampuan membentuk gambar dan ide-ide tentang hal yang tidak pernah dilihat atau dialami sebelumnya. Sehingga imajinasi didefinisikan sebagai kemampuan mental lebih tinggi yang melibatkan proses pemikiran untuk membentuk gambaran, rasa, atau ide-ide tertentu tentang hal yang pernah dialami maupun belum, dan sebagai dasar dari semua kegiatan kreatif. Kemampuan ini digunakan untuk memahami segala sesuatu, salah satunya ilmu pengetahuan. Banyak cabang ilmu dari pohon pengetahuan, dan akar dari pohon itu adalah matematika.

Imajinasi matematika telah banyak diteliti dalam berbagai penelitian proses pembelajaran. Swirski, 2010; Samli, 2011; Kotsopoulos \& cordy, 2009; Alphen, 2011, memberi saran untuk melibatkan imajinasi dalam kegiatan pembelajaran. Tanpa imajinasi, seseorang tidak dapat membayangkan suatu peristiwa dalam sejarah atau masalah verbal dalam matematika (Alphen, 2011). Matematika adalah sebuah ilmu dengan objek kajian yang bersifat abstrak. Abstrak diartikan sebagai sesuatu yang tidak berwujud atau hanya gambaran pikiran. Bentuk pemikiran abstrak mampu memberikan kemampuan kepada manusia untuk menguasai dunia fisik dan memberi pengaruh dalam hampir tiap segi dari kebudayaan manusia. Namun menurut siswa, matematika hanya berisi rumus-rumus yang membosankan sehingga matematika merupakan mata pelajaran yang paling tidak disuka. Kurangnya kreativitas dan inovasi guru dalam pembelajaran matematika dituding menjadi salah satu faktor ketidaksukaan siswa. Terdapat kecenderungan materi pelajaran matematika dipaksa untuk dimengerti dan dihafalkan. Imajinasi siswa salah satunya diperlukan untuk dapat mengantarkan keterkaitan konsep dalam masalah kontekstual. Hoogland et. al. (2016), menegaskan proses dengan melibatkan masalah nyata, akan lebih diterima daripada hanya sekedar hafalan.

Di negara maju, mereka menggunakan daya imajinasi dengan metode-metode pemahaman anak terhadap sesuatu pokok pelajaran. Mereka tidak hanya dituntut paham dengan pelajaran, namun juga mengerti dengan keadaan proses terjadinya sebab akibat, sehingga mereka dapat memahami semua pelajaran yang diberikan termasuk matematika, karena imaginasi adalah kekuatan atau proses untuk menghasilkan kreativitas. Undang-undang Nomor 20 tahun 2003 tentang Sistem Pendidikan Nasional (Sisdiknas), tujuan pendidikan nasional adalah mengembangkan potensi peserta didik agar menjadi manusia yang beriman dan bertakwa kepada Tuha Yang Maha Esa, berakhlak mulia, sehat, berilmu, cakap, kreatif, mandiri, dan menjadi warga negara yang demokratis serta bertangungjawab. Untuk mencapai tujuan pendidikan tersebut, proses pembelajaran harus mengakomodasi berkembangnya potensi-potensi tersebut salah satunya melalui pelajaran matematika.

Terlebih di masa pandemi saat ini, dimana siswa diminta untuk lebih banyak belajar secara mandiri. Sehingga, diperlukan perencaan yang matang sebelum melaksanakan pembelajaran matematika agar siswa dapat mencapai kompetensi yang diharapkan. Perencanaan pembelajaran di Indonesia dinamakan Rencana Pelaksanaan Pembelajaran (RPP). RPP menjadi salah satu komponen yang menentukan dalam keberhasilan pembelajaran. Seperti dalam penelitian terdahulu Mulyatna, F. (2017) dan Mulyatna, F., Indrawati, F., \& Hartati, L. (2018), RPP memiliki peranan yang penting dalam menciptakan suasana pembelajaran. Sehingga, 
dalam situasi pandemi Covid-19, pembelajaran daring membutuhkan daya tangkap yang ekstra dari siswa untuk dapat mengimajinasikan penjelasan dari guru yang hanya melalui daring.

\section{PEMBAHASAN}

Penelitian ini mengkaji mengenai Rencana Pelaksanaan Pembelajaran (RPP) sesuai dengan Kurikulum 2013 Berdasarkan Indikator Kemampuan Imajinasi Matematis Siswa. Sehingga, metode yang digunakan dalam penelitian ini adalah kualitatif dengan jenis penelitian kepustakaan (library research). Sukardi (2010: 34-35) menjelaskan bahwa teknik pengumpulan data yang dilakukan dalam penelitian ini yakni dengan cara membaca literatur yang berkaitan dengan informasi serta relevansi terhadap topik penelitian. Hasil akhir dari penelitian ini yaitu data deskriptif berupa kata-kata yang tertulis dari objek yang diamati. Jenis penelitian ini digunakan dalam mengumpulkan informasi dan data secara mendalam melalui berbagai literatur, baik buku, catatan, jurnal maupun hasil penelitian yang relevan guna memperoleh solusi dari jawaban dan landasan teori mengenai masalah yang akan dikaji. Adapun literatur yang dikaji dalam penelitian ini yakni format RPP Kurikulum 2013 dan indikator Kemampuan Imajinasi Matematis Siswa.

Peraturan Pemerintah (PP) Nomor 19 Tahun 2005 mengisyaratkan bahwa guru diharapkan dapat mengembangkan perencaan pembelajaran. Perencanaan proses pembelajaran meliputi silabus dan RPP. Mulyasa (2007) mengatakan bahwa RPP adalah rencana yang menggambarkan prosedur dan manajemen pembelajaran untuk mencapai satu atau lebih kompetensi dasar yang ditetapkan dalam standar isi yang dijabarkan dalam silabus. Peraturan Menteri Pendidikan dan Kebudayaan (Permendikbud) Nomor 103 Tahun 2014 menyebutkan bahwa RPP merupakan rencana pembelajaran yang dikembangkan secara rinci dari suatu materi pelajaran atau tema tertentu sesuai dengan silabus. Sedangkan, Permendikbud nomor 22 tahun 2016 menjelaskan bahwa RPP adalah rencana kegiatan pembelajaran tatap muka untuk satu pertemuan atau lebih. Pada hakikatnya penyusunan RPP bertujuan merancang pengalaman belajar siswa untuk mencapai tujuan pembelajaran.

Perencanaan proses pembelajaran disesuaikan dengan kurikulum yang berlaku. Penyempurnaan kurikulum yang terakhir terjadi pada tahun 2013. Hidayat (2013: 113) menyatakan bahwa Kurikulum 2013 dicita-citakan untuk melahirkan generasi masa depan yang cerdas komprehensif, yakni tidak hanya cerdas intelektualnya tetapi cerdas emosi, sosial, dan spiritualnya. Permendikbud nomor 70 tahun 2013 menyatakan bahwa Kurikulum 2013 bertujuan untuk mempersiapkan manusia Indonesia agar memiliki kemampuan hidup sebagai pribadi dan warga negara yang beriman, produktif, kreatif, inovatif, dan afektif serta mampu berkontribusi pada kehidupan bermasyarakat, berbangsa, bernegara, dan peradaban dunia. Dilihat dari tujuan Kurikulum 2013, yaitu kreatif dan inovatif maka tidak dapat dilepaskan dari imajinasi. Nemirovsky \& Ferrara (2009) menyatakan bahwa jenis imajinasi tertentu yang dapat dikembangkan dalam pembelajaran matematika disebut imajinasi matematika. Oleh karena itu, RPP yang dibuat guru harus dapat memfasilitasi siswa dalam mengembangkan kemampuan imajinasi matematis. RPP Kurikulum 2013 disebut RPP kurtilas.

Kemampuan imajinasi matematis siswa memiliki beberapa indikator. Nurcahyono, N. A. dkk. (2019) mengemukakan beberapa indikator kemampuan imajinasi matematis sesuai dengan urutan munculnya sebagai berikut.

1. Sensibilitas yakni indikator imajinasi yang mewakili kemampuan individu untuk membangkitkan perasaan selama proses penciptaan.

2. Intuisi yakni indikator imajinasi yang mewakili kemampuan individu untuk menghasilkan asosiasi langsung ke target.

3. Kristalisasi yakni indikator imajinasi yang mewakili kemampuan individu untuk mengekspresikan ideide abstrak dengan menggunakan contoh nyata. 
4. Transformasi yakni indikator imajinasi yang mewakili kemampuan untuk melakukan tugas dengan mengubah pengetahuan di berbagai bidang studi.

5. Eksplorasi yakni indikator imajinasi yang mewakili kemampuan individu untuk mengeksplorasi yang tidak diketahui.

6. Elaborasi yakni indikator imajinasi yang mewakili kemampuan individu untuk mencari perbaikan dengan memformalkan ide.

7. Produtivitas yakni indikator imajinasi yang mewakili kemampuan individu untuk menghasilkan banyak ide.

8. Keefektifan yakni indikator imajinasiyang mewakili kemampuan individu untuk menghasilkan ide-ide efektif untuk tujuan yang diinginkan.

9. Kebaruan yakni indikator imajinasi yang mewakili kemampuan individu untuk menciptakan ide-ide yang tidak biasa.

Sementara itu, dalam Kurikulum 2013 telah termuat karakteristik yang jelas. Hal ini termuat dalam Permendikbud nomor 70 tahun 2013 memaparkan 7 karakteristik Kurikulum 2013, yakni:

1. Mengembangkan keseimbangan antara pengembangan sikap spiritual dan sosial, rasa ingin tahu, kreativitas, kerja sama dengan kemampuan intelektual dan psikomotorik.

2. Sekolah merupakan bagian dari masyarakat yang memberikan pengalaman belajar terencana, dimana siswa menerapkan apa yang dipelajari di sekolah ke masyarakat dan memanfaatkan masyarakat sebagai sumber belajar.

3. Mengambangkan sikap, pengetahuan, dan keterampilan serta menerapkan dalam berbagai situasi di sekolah dan masyarakat.

4. Memberi waktu yang cukup untuk mengembangkan berbagai sikap, pengetahuan, dan keterampilan.

5. Kompetensi dinyatakan dalam bentuk KI kelas yang dirinci lebih lanjut dalam KD mata pelajaran.

6. KI kelas menjadi unsur pengorganisasian $\mathrm{KD}$, dimana semua $\mathrm{KD}$ dan proses pembelajaran dikembangkan untuk mencapai kompetensi yang dinyatakan dalam KI.

7. KD dikembangkan didasarkan pada prinsip akumulatif, saling memperkuat dan memperkaya antar mata pelajaran dan jenjang pendidikan.

Karekteristik Kurikulum 2013 akan mendorong berkembangnya kemampuan imajinasi matematis, terutama pada indikator kristalisasi dan transformasi. Kristalisasi merupakan kemampuan individu untuk mengekspresikan ide-ide abstrak dengan contoh nyata akan tercerminkan dalam menerapkan apa yang dipelajari di sekolah ke masyarakat. Sedangkan, tranformasi merupakan kemampuan untuk melakukan tugas dengan mengubah pengetahuan di berbagai bidang studi akan tercerminkan dalam mengambangkan sikap, pengetahuan, dan keterampilan serta menerapkan dalam berbagai situasi di sekolah dan masyarakat.

Kurikulum 2013 memuat Kompetensi Inti (KI) dan lebih dirinci ke Kompetensi Dasar (KD). KI merupakan kompetensi yang harus dipelajari siswa untuk suatu jenjang sekolah, kelas, dan mata pelajaran. KI terdiri dari sikap (spiritual dan sosial), pengetahuan, dan keterampilan. KI dikelompokkan menjadi 4, yakni sikap spiritual (KI 1), sikap sosial (KI 2), pengetahuan (KI 3), dan keterampilan (KI 4). Dari masingmasing KI dikembangkan ke dalam KD. Sedangkan KD merupakan kompetensi yang dipelajari siswa untuk suatu mata pelajaran di kelas tertentu. KI memberikan ruang kemampuan imajinasi matematis siswa untuk berkembang.

Permendikbud Nomor 37 Tahun 2018 memaparkan masing-masing rumusan KI untuk jenjang SMP kelas 8, dapat dilihat dalam Tabel 1. 
Tabel 1. Rumusan Kompetensi Inti (KI)

\begin{tabular}{ccl}
\hline No. & KI & \multicolumn{1}{c}{ Rumusan KI } \\
\hline 1. & $\begin{array}{c}\text { KI 1 } \\
\text { (Sikap Spiritual) }\end{array}$ & Menghayati ajaran agama yang dianutnya. \\
\hline 2. & $\begin{array}{c}\text { KI 2 } \\
\text { (Sikap Sosial) }\end{array}$ & $\begin{array}{l}\text { Menunjukkan perilaku jujur, disiplin, tanggungjawab, peduli (toleran, gotong } \\
\text { royong), santun, dan percaya diri dalam berinteraksi secara efektif dengan } \\
\text { lingkungan sosial dan alam dalam jangkauan pergaulan dan keberadaannya. }\end{array}$ \\
\hline 3. & $\begin{array}{l}\text { KI 3 } \\
\text { (Pengetahuan) }\end{array}$ & $\begin{array}{l}\text { Memahami dan menerapkan pengetahuan (faktual, konseptual, dan } \\
\text { prosedural) berdasarkan rasa ingin tahunya tentang ilmu pengetahuan, } \\
\text { teknologi, seni, budaya terkait fenomena dan kejadian tampak mata. }\end{array}$ \\
\hline $4 . \quad \begin{array}{l}\text { KI 4 } \\
\text { (Keterampilan) }\end{array}$ & $\begin{array}{l}\text { Mengolah, menyaji, dan menalar dalam ranah konkret (menggunakan, } \\
\text { mengurai, merangkai, memodifikasi, dan membuat) dan ranah abstrak } \\
\text { (menulis, membaca, menghitung, menggambar, dan mengarang) sesuai } \\
\text { dengan yang dipelajari di sekolah dan sumber lain yang sama dalam sudut } \\
\text { pandang/teori. }\end{array}$ \\
\hline
\end{tabular}

Dalam penjabarannya, kemudian perencanaan dalam RPP dapat mengembangkannya dengan memasukkan indikator kemampuan imajinasi matematis. Berdasarkan Tabel 1., kemampuan imajinasi matematis siswa SMP yang dapat dikembangkan, diuraikan lebih lanjut dalam Tabel 2.

Tabel 2. Hubungan Rumusan KI dan Indikator Kemampuan Imajinasi Matematis

$\begin{array}{ccc}\text { Contoh Perilaku } & \text { Indikator } & \text { Keterangan } \\ & \text { Kemampuan } & \\ \text { Imajinasi } & \\ \text { Matematis } & \end{array}$

Rumusan KI-1: menghayati ajaran agama yang dianutnya
1. Perilaku menerima perbedaan karakteristik
Produktivitas, kebaruan
1. Kemampuan imajinasi matematis siswa untuk sebagai anugrah Tuhan yang kebaruan menghasilkan banyak ide dan ide-ide yang tidak Maha Esa
Eksplorasi
2. Selalu menerima penugasan dengan sikap terbuka
Sensibilitas siswa telah belajar mengenai arti perbedaan.
3. Mengakui kebesaran Tuhan dalam menciptakan alam semesta
2. Siswa akan terbiasa untuk mengeksplorasi hal yang belum diketahuinya.
3. Siswa akan menghayati untuk membangkitkan perasaan selama proses penciptaan.

Rumusan KI-2: menunjukkan perilaku jujur, disiplin, tanggung jawab, peduli (toleran, gotong royong), santun, dan percaya diri dalam berinteraksi secara efektif dengan lingkungan sosial dan alam dalam jangkauan pergaulan dan keberadaannya
1. Mau mengakui kesalahan Elaborasi atau kekeliruan
1. Siswa akan membiasakan diri untuk melakukan elaborasi, yaitu mencari perbaikan dalam memformalkan ide.

2. Mengemukakan pendapat sesuai dengan apa yang diyakininya, walaupun berbeda dengan pendapat teman
Kebaruan 2. Siswa akan termotivasi untuk menciptakan ideide yang tidak biasa. 


\begin{tabular}{|c|c|c|}
\hline Contoh Perilaku & $\begin{array}{c}\text { Indikator } \\
\text { Kemampuan } \\
\text { Imajinasi } \\
\text { Matematis }\end{array}$ & Keterangan \\
\hline $\begin{array}{l}\text { 3. Menunjukkan prakarsa } \\
\text { untuk mengatasi masalah } \\
\text { dalam kelompok di } \\
\text { kelas/sekolah }\end{array}$ & & $\begin{array}{l}\text { 3. Siswa akan termotivasi untuk menghasilkan ide- } \\
\text { ide efektif guna tercapainya tujuan yang } \\
\text { diinginkan. }\end{array}$ \\
\hline
\end{tabular}

Rumusan KI-3: memahami dan menerapkan pengetahuan (faktual, konseptual, dan prosedural) berdasarkan rasa ingin tahunya tentang ilmu pengetahuan, teknologi, seni, budaya terkait fenomena dan kejadian tampak mata

\begin{tabular}{lrl}
\hline $\begin{array}{l}\text { mengingat: memberi } \\
\text { contoh, memasangkan }\end{array}$ & Kritalisasi, intuisi & $\begin{array}{r}\text { 1. } \\
\text { Siswa akan terbiasa mengekspresikan ide-ide } \\
\text { abstrak denga menggunakan contoh nyata dan } \\
\text { juga menghasilkan asosiasi langsung ke target. }\end{array}$
\end{tabular}

2. memahami: menemukan Produktivitas

2. Siswa akan distimulasi untuk menghasilkan banyak ide.

3. menerapkan: Keefektifan

3. Siswa akan dilatih untuk menghasilkan ide-ide menyelesaikan masalah

4. menganalisis: membandingkan, Intuisi, eksplorasi efektif untuk tujuan yang diinginkan.

memeriksa

5. mengevaluasi: membuat Intuisi perbandingan

6. mencipta: merencanakan

Keefektifan

4. Siswa akan teratih untuk menghasilkan asosiasi langsung ke target dan mengeksplorasi yang tidak diketahui.

5. Siswa akan dilatih untuk menghasilkan asosiasi langsung ke target.

6. Siswa akan dilatih untuk menghasilkan ide-ide efektif untuk tujuan yang diinginkan.

Rumusan KI-4: mengolah, menyaji, dan menalar dalam ranah konkret (menggunakan, mengurai, merangkai, memodifikasi, dan membuat) dan ranah abstrak (menulis, membaca, menghitung, menggambar, dan mengarang) sesuai dengan yang dipelajari di sekolah dan sumber lain yang sama dalam sudut pandang/teori

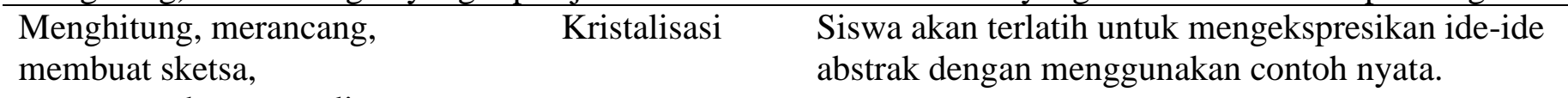

memperagakan, menulis

laporan, menceritakan

kembali, mempraktikan, mendemonstrasikan, menyajikan

Namun demikian, dalam penyusunan RPP tetap ada prinsip-prinsip yang harus diperhatikan. Permendikbud nomor 65 tahun 2013, menjelaskan prinsip-prinsip yang harus diperhatikan dalam menyusun RPP:

1. Perbedaan individual siswa, meliputi kemampuan awal, tingkat intelektual, bakat, potensi, minat, motivasi belajar, kemampuan sosial, emosi, gaya belajar, kebutuhan khusus, kecepatan belajar, latar belakang budaya, norma, nilai, dan atau lingkungan siswa.

2. Partisipasi aktif siswa.

3. Berpusat pada siswa untuk mendorong semangat belajar, motivasi, minat kreativitas, inisiatif, inspirasi, inovasi, dan kemandirian.

4. Pengembangan budaya membaca dan menulis yang dirancang untuk mengembangkan kegemaran membaca, pemahaman beragam bacaan, dan berekspresi dalam berbagai bentuk tulisan. 
5. Pemberian umpan balik dan tindak lanjut RPP, memuat rancangan program pemberian umpan balik positif, penguatan, pengayaan, dan remidi.

6. Penekanan pada keterkaitan dan keterpaduan antara KD, materi pembelajaran, kegiata pembelajaran, indikator pencapaian kompetensi, penilaian, dan sumber belajar dalam satu keutuhan pengalaman belajar.

7. Mengakomodasi pembelajaran tematik-terpadu, keterpaduan lintas mata pelajaran, lintas aspek belajar, dan keragaman budaya.

8. Penerapan teknologi informasi dan komunikasi secara terintegrasi, sistematis, dan efektif sesuai dengan situasi dan kondisi.

Prinsip-prinsip tersebut akan mendorong berkembangnya kemampuan imajinasi matematis siswa. RPP dibuat dengan mempertimbangkan individu siswa, sehingga kemampuan imajinasi matematis yang dikembangkan sesuai dengan kemampuan yang dimiliki siswa. Indikator kemampuan imajinasi matematis disusun berdasarkan urutan munculnya pada siswa. kemampuan Imajinasi matematis terletak di alam pikiran siswa, sehingga akan muncul jika terdapat partisipasi aktif dari siswa dan pembelajaran berpusat pada siswa. Memberi umpan balik akan mendorong berkembangnya kemampuan imajinasi matematis siswa terutama pada indikator elaborasi. siswa akan mencari perbaikan dengan memformalkan ide.

Penekanan terjadi pada keterkaitan/keterpaduan antara indikator dan mengakomodasi pembelajaran tematik-terpadu, keterpaduan lintas mata pelajaran, lintas aspek belajar, dan keragaman budaya juga akan mengembangkan imajinasi matematis khususnya transformasi. Dengan keterkaitan dan keterpaduan, siswa akan melakukan tugas dengan mengubah pengetahuan di berbagai bidang studi. Penerapan teknologi informasi dan komunikasi secara terintegrasi, sistematis, dan efektif sesuai dengan situasi dan kondisi akan meningkatkan kemampuan imajinasi matematis. Siswa dapat mengeksplorasi sesuatu yang tidak diketahui melalui teknologi informasi dan komunikasi. Melalui penerapan teknologi informasi dan komunikasi, siswa dapat memperoleh sumber untuk merangsang banyak ide, dan ide-ide yang efektif untuk tujuan yang diinginkan serta menciptakan ide-ide yang tidak biasa.

Selanjutnya, Permendikbud nomor 22 tahun 2016 memaparkan beberapa komponen dari RPP yang dapat dikembangkan berdasarkan indikator imajinasi matematis sebagai berikut:

1. Tujuan pembelajaran yang dirumuskan berdasarkan KD, dengan menggunakan kata kerja operasional yang dapat diamati dan diukur, yang mencakup sikap, pengetahuan, dan keterampilan.

2. KI, KD, dan indikator pencapaian kompetensi.

3. Metode pembelajaran yang digunakan oleh pendidik untuk mewujudkan suasana belajar dan proses pembelajaran agar siswa mencapai KD yang disesuaikan dengan karakteristik siswa dan KD yang akan dicapai.

4. Media pembelajaran, berupa alat bantu proses pembelajaran untuk menyampaikan materi pelajaran.

5. Sumber belajar, dapat berupa buku, media cetak dan elektronik, alam sekitar, atau sumber belajar lain yang relevan.

6. Langkah-langkah pembelajaran dilakukan melalui tahapan pendahuluan, inti, dan penutup.

Berdasarkan beberapa komponen RPP tersebut, kemampuan imajinasi matematis siswa SMP yang dapat dikembangkan, sebagaimana dapat dilihat dalam Tabel 3. 
Tabel 3. Hubungan Komponen RPP dan Indikator Kemampuan Imajinasi Matematis

\begin{tabular}{|c|c|c|}
\hline No & Komponen RPP & Keterangan \\
\hline 1 & Tujuan pembelajaran & $\begin{array}{l}\text { Untuk menyusun RPP yang dapat mengembangkan kemampuan imajinasi } \\
\text { matematis siswa, maka dalam menentukan tujuan pembelajaran harus } \\
\text { memuat kata kerja operasional yang dapat diamati dan diukur, yang } \\
\text { mencakup sikap, pengetahuan, dan keterampilan dalam mengembangkan } \\
\text { kemampuan imajinasi matematis berdasarkan KD. }\end{array}$ \\
\hline 2 & $\begin{array}{l}\text { KD dan indikator } \\
\text { pencapaian kompetensi }\end{array}$ & $\begin{array}{l}\text { KD merupakan uraian dari KI. Untuk mengembangkan kemampuan } \\
\text { imajinasi matematis siswa, menyusun KD dengan memuat kata kerja } \\
\text { operasional yang dapat diamati dan diukur seperti memberi contoh, } \\
\text { memasangkan, menemukan, menyelesaikan masalah, membandingkan, } \\
\text { memeriksa, membuat perbandingan, merencanakan. }\end{array}$ \\
\hline 3 & Metode pembelajaran & $\begin{array}{l}\text { Metode pembelajaran yang dapat digunakan untuk mengembangkan } \\
\text { kemampuan imjinasi matematis siswa, contohnya yaitu project based } \\
\text { learning (PBL). Metode pembelajaran ini dapat membuat siswa } \\
\text { menciptakan suatu produk pembelajaran matematika, misalnya pada } \\
\text { artikel materi tertentu. Untuk membuat artikel tersebut, siswa akan } \\
\text { menggunakan kemampuan menciptakan, menghasilkan asosiasi, } \\
\text { memberikan contoh nyata, menggunakan pengetahuan dalam berbagai } \\
\text { bidang studi, mengeksplorasi, memformalkan ide, menghasilkan banyak } \\
\text { ide, menghasilkan ide-ide efektif, dan menciptakan ide-ide yang tidak } \\
\text { biasa. }\end{array}$ \\
\hline 4 & Media pembelajaran & $\begin{array}{l}\text { alat bantu proses pembelajaran yang digunakan untuk menyampaikan } \\
\text { materi pelajaran dapat membantu siswa untuk memahami materi yang } \\
\text { tengah disampaikan secara visual, audio, maupun audiovisual sehingga } \\
\text { membantu imajinasi matematis di pikiran siswa. }\end{array}$ \\
\hline 5 & Sumber belajar & $\begin{array}{l}\text { Pemilihan sumber belajar juga perlu diperhatikan. Sumber belajar dapat } \\
\text { berupa buku, media cetak dan elektronik, alam sekitar, atau sumber belajar } \\
\text { lain yang relevan. Sumber belajar alam sekita misalnya akan membuat } \\
\text { siswa dapat mengekspresikan ide-ide abstrak dengan menggunakan contoh } \\
\text { nyata. }\end{array}$ \\
\hline & Langkah-langkah & $\begin{array}{l}\text { Dilakukan melalui tahapan pendahuluan, inti, dan penutup. Pada tahapan- } \\
\text { tahapan ini, misal dalam pendahuluan perlu dilakukan kegiatan kuis } \\
\text { misalnya. Kuis akan membuat siswa mengeksplorasi yang tidak } \\
\text { diketahuinya. Eksplorasi akan dilakukan pada saat inti pelajaran. Dengan } \\
\text { demikian, siswa akan mengembangkan kemampuan imajinasi } \\
\text { matematisnya selama pembelajaran. }\end{array}$ \\
\hline
\end{tabular}

Dengan demikian, di dalam penyusunan RPP, dapat dikembangkan dengan mengacu pada proses imajinasi siswa. Pembelajaran daring tetap harus ada perencanaan yang baik. Kajian literatur ini diharapkan menjadi alternatif sumber referensi dalam proses perencanaan pembelajaran di masa pandemi Covid-19 maupun dalam mempersiapkan era kenormalan baru. 


\section{SIMPULAN}

RPP Kurikulum 2013 untuk pelajaran matematika telah cukup mengakomodasi munculnya indikator kemampuan imajinasi matematis siswa. Guru memiliki kebebasan dalam mengembangkan RPP sesuai dengan tujuan pencapaiannya masing-masing. RPP yang dikembangkan tersebut harus memuat komponenkomponen yang sudah diberikan. Dengan demikian, RPP Kurikulum 2013 memberikan ruang untuk guru dalam mengembangkan kemampuan imajinasi matematis siswa.

\section{DAFTAR RUJUKAN}

Alphen, P. Van. (2011). Imagination as a Transformative Tool in Primary School Education. RoSE Research on Steiner Education. 2 (2), 16-34.

Calaprice, A. 2011. The Ultimate Quotable Einstein. US: Princeton University Press.

Hidayat, S. 2013. Pengembangan Kurikulum Baru. Bandung: Remaja Rosdakarya.

Hoogland, K., Pepin, B., Bakker, A., de Koning, J., \& Gravemeijer, K. (2016). Representing contextual mathematical problems in descriptive or depictive form: Design of an instrument and validation of its $\begin{array}{lllll}\text { uses. Studies in } & \text { Educational }\end{array}$ https://doi.org/https://doi.org/10.1016/j.stueduc.2016.06.005

Kementerian Pendidikan dan Kebudayaan Republik Indonesia. 2014. Pembelajaran Pada Pendidikan Dasar dan Pendidikan Menengah. Peraturan Menteri Pendidikan dan Kebudayaan Nomor 103 Tahun 2014. Biro Hukum dan Organisasi Kementerian Pendidikan dan Kebudayaan. Jakarta.

Kementerian Pendidikan dan Kebudayaan Republik Indonesia. 2016. Standar Proses Pendidikan Dasar dan Menengah. Peraturan Menteri Pendidikan dan Kebudayaan Nomor 22 Tahun 2016. Biro Hukum dan Organisasi Kementerian Pendidikan dan Kebudayaan. Jakarta.

Kementerian Pendidikan dan Kebudayaan Republik Indonesia. 2013. Kerangka Dasar dan Struktur Kurikulum Sekolah menengah Kejuruan / Madrasah Aliyah Kejuruan. Peraturan Menteri Pendidikan dan Kebudayaan Nomor 70 Tahun 2013. Biro Hukum dan Organisasi Kementerian Pendidikan dan Kebudayaan. Jakarta.

Kementerian Pendidikan dan Kebudayaan Republik Indonesia. 2018. Perubahan Atas Peraturan Menteri Pendidikan Dan Kebudayaan Nomor 24 Tahun 2016 Tentang Kompetensi Inti dan Kompetensi Dasar Pelajaran Pada Kurikulum 2013 Pada Pendidikan Dasar Dan Pendidikan Menengah. Peraturan Menteri Pendidikan dan Kebudayaan Nomor 37 Tahun 2018. Biro Hukum dan Organisasi Kementerian Pendidikan dan Kebudayaan. Jakarta.

Kementerian Pendidikan dan Kebudayaan Republik Indonesia. 2013. Standar Proses Pendidikan Dasar dan Menengah. Peraturan Menteri Pendidikan dan Kebudayaan Nomor 65 Tahun 2013. Biro Hukum dan Organisasi Kementerian Pendidikan dan Kebudayaan. Jakarta.

Kotsopoulos, D., \& Cordy, M. (2009). Investigating Imagination as a Cognitive Space For Learning Mathematics. Educational Studies in Mathematics. 70 (3), 259-274.

Mulyasa, E. (2007). Kurikulum Tingkat Satuan Pendidikan. Bandung: PT. Remaja Rosdakarya.

Mulyatna, F. (2017). Analysis Lesson Plan Mathematics by Curriculum 2013 Implementation Using Inquiry Method. 993-1001. Proceedings International Conference on Education and Science (ICONS 2017).

Mulyatna, F., Indrawati, F., \& Hartati, L. (2018). PELATIHAN PEMBUATAN RENCANA PELAKSANAAN PEMBELAJARAN BERDASARKAN KURIKULUM 2013 DI YAYASAN RAUDLATUL JANNAH. Abdimas Dewantara, 1(1), 11-22. http://jurnal.ustjogja.ac.id/index.php/abdimasdewantara/article/viewFile/2128/1460 
Nemirovsky, R., \& Ferrara, F. Mathematical Imagination and Embodied Cognition. Educational Studies in Mathematics. 2009; 70(2): 159-174.

Nurcahyono, N. A., Suryadi, D., Novarina, E., \& Prabawanto, S. Complications of Students in Eliciting Mathematical Imagination. Proceedings of 2019 The World Symposium on Software Engineering. September 20-23, Wuhan, China.

Peraturan Pemerintah Republik Indonesia Nomor 19 Tahun 2005 Standar Nasional Pendidikan. 16 Mei 2005. Lembaran Negara Republik Indonesia Tahun 2005 Nomor 41. Jakarta.

Samli, A. C. (2011). From Imagination to Innovation: New Product Development For Quality of Life. New York: Springer.

Swirski, T. (2010). Unleashing the Imagination in Learning, Teaching and Assessment: Design Perspectives, Innovative Practices and Meaning Making. PhD Candidate, Macquarie University.

Undang-Undang Republik Indonesia Nomor 20 tahun 2003 Tentang Sistem Pendidikan Nasional. 8 Juli 2003. Lembaran Negara Republik Indonesia Tahun 2003 Nomor 4301. Jakarta.

Vygotsky, L. S. (2004). Imagination and creativity in childhood. Journal of Russian and East European Psychology, 42 (1), 7-97.

Wikipedia Ensiklopedia. 2020. Imagination. Diakses pada tanggal 25 Januari 2020. Url: https://en.wikipedia.org/wiki/Imagination. 